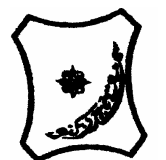

Bayero Journal of Pure and Applied Sciences, 6(2): 76 - 83

Received: January 2013

Accepted: November 2013

ISSN $2006-6996$

\title{
INFLUENCE OF TILLAGE PRACTICES ON PHYSICAL PROPERTIES OF A SANDY LOAM IN SEMI-ARID REGION
}

\author{
${ }^{1}$ Sauwa, M.M., ${ }^{2}$ Waniyo, U.U., ${ }^{2}$ Ngala, A.L., ${ }^{3}$ Yakubu, M. and ${ }^{1}$ Noma, S.S. \\ ${ }^{1}$ Department of Soil Science and Agricultural Engineering, Faculty of Agriculture, Usmanu Danfodiyo University, \\ PMB 2346, Sokoto. \\ ${ }^{2}$ Department of Soil Science, Faculty of Agriculture, University of Maiduguri. \\ ${ }^{3}$ Department of Crop Production, IBB University, Lapai, Niger State \\ Correspondence author: mmsauwa4u@yahoo.com
}

\begin{abstract}
The contrasts observed in soil tillage research studies documented the need for more research in many regions of the world if the mechanics of tillage effects on soil physical properties is to be well understood. Thus, the effect of three tillage systems: no-tillage (NT), reduce tillage (RT) and conventional tillage (CT) on the physical properties of a sandy loam soil in Maiduguri, Nigeria was investigated after 9-15 years of management. During the growing season of 2010, triplicate undisturbed core samples ( $5.5 \mathrm{~cm}$ in diameter and $4 \mathrm{~cm}$ height) were obtained at two soil depths (0$15 \mathrm{~cm}$ and $15-30 \mathrm{~cm})$, for determination of volumetric $(\theta v)$ moisture content, bulk density $(B d)$, and total porosity (TP) of the soil at selected dates, while soil penetration resistance (PR) was determined using hand held digital penetrometer. Tillage systems significantly $(p \leq 0.05)$ affected $B d$ and TP of the soil at two of the four sampling dates. The $R T$ treatment recorded highest $B d$ and lowest TP at $(0-15 \mathrm{~cm})$ depth across most sampling dates, while at $(15-30 \mathrm{~cm})$ soil depth, the CT and $R T$ treatments maintained higher Bd. Soil PR was significantly influenced by tillage systems only at the surface $(0-15 \mathrm{~cm})$ soil depth. The $N T$ treatment recorded significantly $(p \leq 0.05)$ higher PR while the $R T$ treatment recorded the least. Further, significant $(p \leq 0.05)$ tillage treatment effects on the $\theta v$ content of the soil was observed at both surface $(0-15 \mathrm{~cm})$ and sub surface $(15-30 \mathrm{~cm})$ soil depths. The NT and RT treatments, on average, recorded higher values of $\theta v$ relative to the $C T$ treatment. Soil organic carbon (OC) and aggregate stability in water (MAW, ASC, DR and WSI) were found to correlate $(p<0.05)$ well with $\theta v$ content of the soil for most sampling dates particularly a surface soil

layer.

The study revealed that, the NT and RT treatments promotes better physical quality of the soil relative to the CT treatment. It ishowever recommended that, other reduced tillage systems suc $h$ as animal traction and ridgetillage be tried to assess their efficacy of improving soil physical $q$ uality.
\end{abstract}

Key words: Tillage, Tillage systems, Soil Physical properties, Moisture storage, Physical quality

\section{INTRODUCTION}

Soil tillage is one of the fundamental agrotechnical operations in agriculture because of its influence on soil properties, environment and crop production in general (Husnjak et al., 2002). This influence of tillage on soil properties and crop production had motivated numerous workers to investigate tillage effects on soil physical properties (Dao, 1993; Mielke et al., 1984; Khan et al., 2001; Jabro et al., 2008), however, results obtained by these and other workers as indicated by the below literature seems contradictory.

For example, while Alegre et al. (1991) observed higher bulk density (Bd) in minimum till (MT) and notill (NT) systems relative to the conventional tillage (CT) treatment, Logsdon and Cambardella (2000) reported no significant effect of tillage systems on the $\mathrm{Bd}$ of a fine loam soil. Increased water storage had also been associated with conservation tillage practices (Dao, 1993; Agbede, 2007), this increase in water storage of conservation tillage systems had been attributed to decreased evaporation (Dao, 1993), greater organic carbon contents (Agbede, 2007;
Golchin and Asgari, 2008) and greater aggregate strength (Milton da Viega et al., 2009). However, Jabro et al. (2008) reported no significant effect of tillage systems on water storage of a sandy loam soil after 22 years of tillage implementation. Further, while Jabro et al. (2008) reported significantly higher penetration resistance (PR) in conservation tillage practices relative to the conventional system, Mielke et al. (1984) observed no significant effect of tillage systems on soil PR after longer period of tillage imposition. These contrasts observed had been related to several things including soil type (Azooz and Arshad, 1996), kind of tillage practiced, soil moisture conditions before tillage, and climatic characteristics especially the pattern and magnitude of precipitation (Mapa et al., 1986).

From the foregoing, the need for more research on tillage effects upon soil physical properties in many regions of the world became pertinent, if the mechanics of tillage effects on soil physical properties are to be well understood. The aim of this study was therefore to evaluate the effects of different tillage practices on some physical properties of the soil. 


\section{MATERIALS AND METHODS The Study Area}

The study was carried out in Maiduguri, north east Nigeria. Climate of Maiduguri is semi arid with longterm mean annual rainfall (1961-1990) of $553 \mathrm{~mm}$. Rainfall distribution

unimodal, starting on the average in mid -

June and lasting until the end of September (Gre ma and Hess, 1994). Five sites were used for the study. The sites were selected based on their land use history. Soil of the study area is Sandy loam (Table 1a and b). GPR equipment (12 channel GPS etrex, courtesy GARMIN Corporation 1999-

2002) was used in determining coordinates of the sites.

\section{Treatments and Experimental Design}

The experiment was established as randomize complete block design (RCBD) with three tillage treatments and five replications. Three tillag e treatments namely; no tillage(NT), reduce tillage $(\mathrm{RT})$ and conventional tillage $(\mathrm{CT})$ were evaluated on each site.

The CT treatment in the five selected sites involved 1-2 tractor harrow passes per season (year), and the commonly grown crops in this treatment (CT) are groundnut, cowpea, millet or maize. While the RT treatment in all selected sites involved 1-2 hand hoe cultivation per season (year), and the commonly grown crops in this treatment (RT) are groundnut, cowpea or millet. The NT treatment in all selected sites comprises of uncultivated lands left fallowed under natural vegetation. In addition, the CT and RT treatments are either opposite or adjacent to the uncultivated (NT) plots. All treatments (CT, RT and NT) in the selected sites were under management for a period of about 9-15 years. NPK and phosphate fertilizers are the commonly applied fertilizers by farmers in the cultivated plots (CT and RT). The commonly found plant species and locations of the five selected sites are as follows:

SITE1: University of Maiduguri Teaching and Research Farm $\left(11^{\circ} 54^{\prime} \mathrm{N}, 13^{\circ} 5^{\prime} \mathrm{E}\right)$.

The dominant plant species in this area are Andropogon gayanum, Cenchrus biflorus, and scattered Azadirachta indica trees.

SITE 2: Livestock Farm, University of Maiduguri $\left(11^{\circ} 47.6^{\prime} \mathrm{N}\right.$, $\left.13^{\circ} 12.5^{\prime} \mathrm{E}\right)$.

In this site, the commonly found plant species are Senna obtusfolia, Achyranthes asper L., and scattered Balanites aegyptica trees.

SITE3: Kwayam Village, off University of Mai duguri $\left(11^{\circ} 47.9^{\prime} \mathrm{N}, 13^{\circ} 12.6^{\prime} \mathrm{E}\right)$.

This site is characterized by scattered Piliostigma reticulatum and Faidherbia albida trees likewise Cenchrus biflorus and Imperata cylindrica as dominant vegetation.

SITE 4: Old Malumbrari Primary School, Maiduguri $\left(11^{\circ} 47^{\prime} \mathrm{N}, 13^{\circ} 12.7^{\prime} \mathrm{E}\right)$.

In site 4 , the commonly found plant species are Senna obtusfolia, Achyranthes asper L., Zizuphus mauritiana and Balanites aegyptica trees.
SITE 5: University of Maiduguri Commercial Farm $\left(11^{\circ} 47.61^{\prime} \mathrm{N}, 13^{\circ} 13.04^{\prime} \mathrm{E}\right)$.

At this site, the dominant plant species found are Cenchrus biflorus, Achyranthes asper L., Senna obtusfolia, and scattered Balanites aegyptica trees.

The five selected sites were within close proximity $(40-80 \mathrm{~m})$ of one another, and within each selected site, treatment plots are located within 40-60 $\mathrm{m}$ of one another and had similar terrain and parent material (Aeolian sand). During the growing season of 2010, triplicate undisturbed core samples $(5.5 \mathrm{~cm}$ in diameter and $4 \mathrm{~cm}$ height) were obtained at four selected dates for the determination of bulk density (Bd), total porosity (TP) and volumetric moisture content $(\Theta v)$ of the soil, while penetration resistance of the soil was determined using hand held digital penetrometer (D 1558-84 ASTM standard of needle head $0.6 \mathrm{~cm}$ ). The bulk density was determined using the core method as described by Blake and Hartage (1986), while gravimetric moisture content $(\Theta \mathrm{g})$ was determined by direct method as described by Hillel (1971). The $\Theta \mathrm{g}$ was then converted to $\Theta v$ using the following relation :

$\Theta v=\Theta g \times B d$

Where $\mathrm{Bd}=$ bulk density

The soil physical properties were determined at two soil depths (0-15 and $15-30 \mathrm{~cm})$ to capture cultivation zone around the experimental area. The two soil depths were determined using measuring tape and one profile was dug in each treatment plot to observe profile characteristics.

\section{Aggregate properties and organic carbon determination}

Macro aggregates of wet (MAW) and macro aggregates of dry (MAD) aggregates were determined after determination of mean weight diameter (MWD) of wet and dry aggregates as described by Kemper (1965) and Kemper and Chepil (1965) respectively. While aggregate silt-plus clay (ASC \%), water stability index (WSI \%), dispersion ratio (DR \%) and organic carbon (OC) contents of soil samples were determined as follows:

Aggregate silt-plus clay (ASC \%): This is defined as the difference between silt + clay in calgon dispersed and that in water -

dispersed soil samples (Middleton, 1930).

Water stability index (WSI \%): This was computed as 100 ( $1-A / B)$. Where $A$ is percentage of aggregates which passed a $0.20 \mathrm{~mm}$ sieve in 5 minutes after shaking at the rate of 60 oscillations per minute at room temperature and $B$ is the percentage that passed after 60 minutes under the same conditions (Malquori and Cecconi, 1962). Dispersion ratio was computed as $D R=(A / B) \times 100$. Where $A=$ Percent silt + clay in water - dispersed sample, and $\mathrm{B}=$ Percent silt + clay in calgondispersed sample (Middleton, 1930). Organic carbon (OC) : The organic carbon content of soil samples was determined by wet oxidation method of Walkley and Black (1934). 


\section{Statistical Analysis}

Statistical analysis system (SAS) version 2005 analytic al software was used in analyzing data obtained. T he results obtained were analyzed using analysis of variance (ANOVA) statistics and means were separated using least significant differe nce (LSD) test at $5 \%$ level of probability.

\section{RESULTS AND DISCUSSION}

\section{Particle size distribution (Texture)}

Tillage treatments effects on textural composition (\% sand, silt and clay) of the soil are presented in Table $1 a$ and $b$. Tillage treatments had no significant effect on the \% sand, silt and clay contents of the soil at surface $(0-15 \mathrm{~cm})$ soil depth (Table 1a). However, at the sub surface (15$30 \mathrm{~cm}$ ) soil depth, tillage practices significantly ( $p \leq$ 0.05 ) influenced textural composition of the soil. The NT and RT treatments had higher sand contents (67.8 and 67.3 respectively) relative to the CT treatment (64.3). Similarly, tillage treatments effect on clay content of the soil at the sub surface soil depth was also significant. The RT treatment gave the highest clay content (14.85) followed by the CT (13.35), then NT treatment (12.35) Table 1b. No significant treatments effect on the silt content of the soil at both the surface and sub surface soil depths was observed. The result agrees with findings of Mbagwu and Bazzoffi (1989) who reported that cultivation encourages movement of finer soil particle (clay) within the soil profile. Generally, values of sand contents of the soil decreased with depth, while those of clay content increased with depth irrespective of tillage treatment (Table $1 a$ and $b$ ).

\section{Soil bulk density (Bd) and total porosity (TP)}

Result of soil Bd and TP measurement for the various treatments at various sampling dates are presented in Table 2 . No consistent trend in $\mathrm{Bd}$ and TP of the soil was observed with time at the surface $(0-15 \mathrm{~cm})$ soil layer during crop growing season. However, at the subsurface $(15-30 \mathrm{~cm})$ soil layer, the CT treatment showed a trend of increasing Bd as the raining season progressed. Generally, Bd of the soil increased with increasing soil depth irrespective of tillage method (Table 2). In addition, Bd and TP of the soil were significantly ( $p \leq 0.05$ ) influenced by tillage systems only during two of the four sampling $d$ ates.

In general, the $\mathrm{CT}$ treatment had the least $\mathrm{Bd}$ and the highest TP at the surface soil layer compared to either the NT or RT treatments during all the measurement dates. This could be attributed to the loosening effect of tillage equipment used for the CT treatment (Barzegar et al., 2004). The trend reversed at the sub surface soil layer with the $\mathrm{CT}$ and RT treatments having relatively higher values of $\mathrm{Bd}$ and lower values of TP compared to the NT treatment irrespective of measurement date (Table 2). The higher Bd recorded in the sub surface soil layer of the CT treatment could be attributed to the effect of tractor wheel traffic as observed by previous workers (Mielke et al.,1984; Heddadj and GascuelOdoux,1999). Excavation of profiles displayed a fairly dense layer at about $20-40 \mathrm{~cm}$ of all the CT treatments further supporting densification of soil matrix at the sub surface soil layer by the CT treatment. The results revealed that the CT and NT treatments offer significant advantage over the RT treatment in ensuring good aeration status of the soil, and ease of root penetration (particularly shortly after tillage imposition). However, studies have shown that for the CT treatment, these conditions diminished rapidly due to aggregate disruption by rain drop impact (Moran et al., 1988) and soil consolidation after pulverization (Suwardji and Eberbach,1998). Values of Bd ovserved in this study generally seems high and are relatively approaching critical $\mathrm{Bd}$ value $\left(1.90 \mathrm{~g} / \mathrm{cm}^{3}\right)$ considered as root limiting in coarse textured soils (Marshall and Tokunaga, 2006). Therefore, practices that reduce soil Bd such as crop residue mulch incorporation should be encouraged.

\section{Penetration resistance (PR)}

Tillage treatment effects on soil PR $(\mathrm{kPa})$ are presented in Fig.1. Tillage systems significantly ( $p \leq 0.05)$ affected the soil PR only at the surface (0$15 \mathrm{~cm})$ soil layer. The NT treatment recorded significantly ( $p \leq 0.05)$ higher PR value $(238.6 \mathrm{kPa})$ at the surface soil layer relative to the RT $(173 \mathrm{kPa})$ and CT (187.5 kPa) treatments (Fig.1). However, the RT treatment recorded lowest PR at both surface (173 $\mathrm{kPa})$ and sub surface $15-30 \mathrm{~cm}(95.90 \mathrm{kPa})$ soil layers compared to the NT and CT treatments (Fig.1). The trend in PR among treatments reported in this study is quite unexpected because results of previous studies conducted on similar soils showed the existence of a direct positive correlation between Bd and PR (Khan et al., 2001; Jabro et al., 2008) indicating that higher values of $\mathrm{Bd}$ are associated with higher values of PR. However, this ambiguity could be associated with soil moisture (gravimetric) content at time of sampling which had been reported to decrease soil PR (Ghuman and Lal, 1984). The average moisture content for the NT, RT and CT treatments at the time of sampling were $0.35,0.55,0.34$ and $1.21,1.41$ and 1.20 (\%, $\mathrm{g} / \mathrm{g}$ ) for the surface and sub surface soil layers respectively. Further, soil PR values observed are generally low irrespective of tillage method and quite far from the critical PR value $(2000 \mathrm{kPa})$ reported to be detrimental to root penetration in soils (Dec et al., 2011). In general, the results of Bd, TP and PR of the soil showed evidence of compaction by NT and RT treatments at surface soil layer, while the CT treatment showed compaction at the sub surface layer.

\section{Soil moisture content}

Moisture content of the soil was significantly ( $p \leq$ 0.05 ) influenced by tillage systems. The results of effect of tillage systems on the volumetric moisture content $(\Theta v)$ of the soil for the various sampling dates are presented in Table 3. No consistent trend in $\Theta \mathrm{v}$ content of the soil was observed as the raining season progressed.

However, the NT and RT treatments consistently retained more moisture at both surface $(0-15 \mathrm{~cm})$ and sub surface $(15-30 \mathrm{~cm})$ soil layers relative to the CT treatment during most sampling dates (Table 3 ). 
In addition, the NT and RT treatments on average, recorded significantly ( $p \leq 0.05$ ) higher $\Theta v$ contents at both surface and sub surface soil layers compared to the CT treatment across most of the sampling dates (Table 3). The $\theta v$ contents of the soil significantly ( $p$ $<0.05)$ correlated positively with organic carbon (OC) content and aggregate stability indices (ASC, MAW, MAD and WSI) of the soil at surface $(0-15 \mathrm{~cm})$ soil layer, while DR of the soil correlated negatively (Table 4a). However, at the sub surface soil depth, some of these parameters correlated $(p<0.05)$ with $\Theta v$ content of the soil only for the first and the last sampling dates (Table 4b). MAW and ASC significantly correlated positively, while DR of the soil negatively correlated significantly with $\Theta v$ content of the soil(Table 4b). It is not clear why most of the parameters did not correlate significantly with $\Theta v$ content of the soil at the sub surface soil depth, this could however be related to decreased organic carbon content with depth as observed in a companion report on chemical quality of the soil (Sauwa et al., 2012) which might have generated varied responses. The results are however in line with findings of Agbede (2007) and Golchin and Asgari (2008) who reported that, OC/organic matter contents of soils exerts great influe nce on soil moisture content.

The regression equations relating $\mathrm{OC}$ and
$\Theta v$ content of the soil at surface $(0-15 \mathrm{~cm})$ are presented as follows:

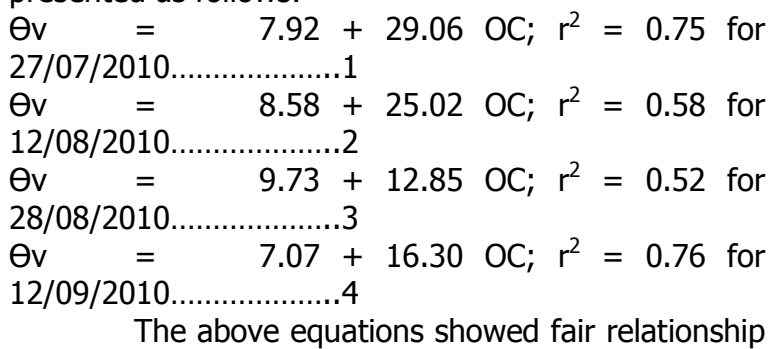
of $\mathrm{OC}$ and $\Theta \mathrm{v}$ content of the soil, with best relationship observed for the first sampling date (27/07/2010). Previous workers had related greater moisture contents of NT and/or RT treatments to their greater organic carbon contents (Agbede, 2007; Golchin and Asgari, 2008). Likewise, Milton da veiga et al. (2009) reported greater soil moisture contents of tillage treatments due to greater aggregate stability in water. Therefore, the greater moisture content of the NT and RT relative to the CT treatment could be attributed to greater OC content and aggregate strength of these treatments compared to the CT treatment. The results obtained in this study are in agreement with findings of (Khakural et al., 1992; Agbede, 2007) who reported greater moisture contents in conservation tillage practices relative to the conventional system.

Table 1a. Percentage sand, silt and clay contents of the soil as affected by tillage systems for 0-15 soil depth

\begin{tabular}{ccccc}
\hline Treatments & (\% sand) & (\% silt) & (\% clay) & Textural class \\
\hline NT & & $\mathbf{0 - 1 5} \mathbf{~ c m}$ & & \\
1 & 72.1 & & & Sandy loam \\
2 & 67.1 & 18.2 & 9.7 & Sandy loam \\
3 & 69.6 & 20.7 & 12.2 & Sandy loam \\
4 & 69.6 & 20.7 & 9.7 & Sandy loam \\
5 & 69.6 & 18.2 & 12.2 & Sandy loam \\
Mean & $\mathbf{6 9 . 6}$ & 20.7 & 9.7 & \\
RT & & $\mathbf{1 9 . 7}$ & $\mathbf{1 0 . 7}$ & Sandy loam \\
1 & 69.6 & & 12.2 & Sandy loam \\
2 & 72.1 & 18.2 & 7.2 & Sandy loam \\
3 & 69.6 & 20.7 & 9.7 & Sandy loam \\
4 & 69.6 & 20.7 & 12.2 & Sandy loam \\
5 & 67.1 & 18.2 & 12.2 & \\
Mean & $\mathbf{6 9 . 6}$ & $\mathbf{1 0 . 7}$ & & Sandy loam \\
CT & & & 12.7 & Sandy loam \\
1 & 72.1 & 15.7 & 12.2 & Sandy loam \\
2 & 72.1 & 18.2 & 9.7 & Sandy loam \\
3 & 69.6 & 18.2 & 12.2 & Sandy loam \\
4 & 67.1 & 23.2 & 9.7 & \\
5 & 69.6 & 18.2 & 12.2 & $\mathbf{1 1 . 3}$ \\
Mean & $\mathbf{7 0 . 1}$ & $\mathbf{1 8 . 7}$ & $\mathbf{N S}$ &
\end{tabular}

${ }^{1}$ NS- not significant at $p \leq 0.05$ level of probability

2 1....5- replications 


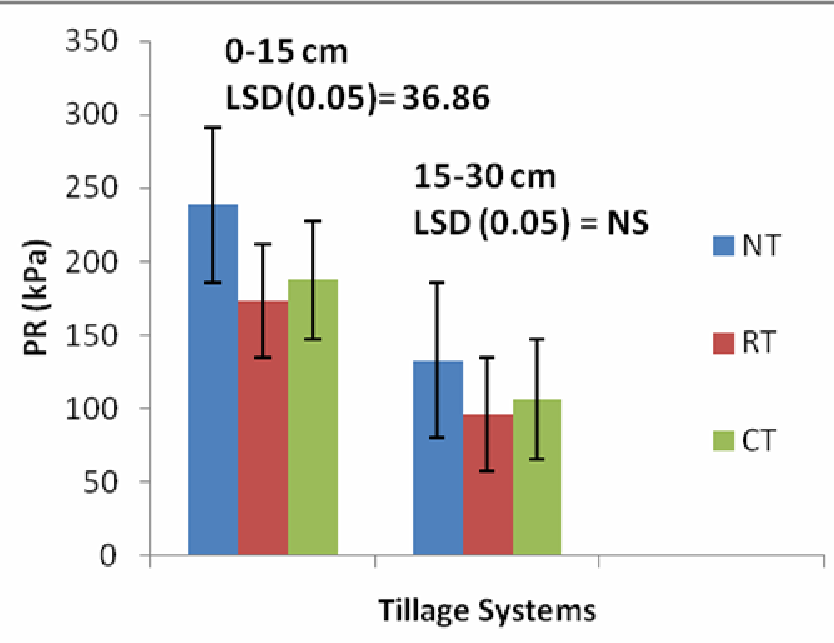

Figure 1: Effect of tillage systems on mean penetration resistance (PR) of the soil 15 and $15-30 \mathrm{~cm}$ soil depths (bars indicate standard error)

(kPa) at 0-

Table 1b: Percentage sand, silt and clay contents of the soil as affected by tillage systems for 15-30 cm soil depth

\begin{tabular}{ccccc}
\hline Treatments & (\% sand) & (\% silt) & (\% clay) & Textural class \\
\hline NT & & $\mathbf{1 5 - 3 0 ~} \mathbf{~ m}$ & \\
1 & 70.3 & & & \\
2 & 65.3 & 14.35 & 15.35 & Sandy loam \\
3 & 67.8 & 24.35 & 10.35 & Sandy loam \\
4 & 67.8 & 19.35 & 12.85 & Sandy loam \\
5 & 67.8 & 19.35 & 12.85 & Sandy loam \\
Mean & $\mathbf{6 7 . 8}$ & 19.35 & 12.85 & Sandy loam \\
RT & & $\mathbf{1 9 . 3 5}$ & $\mathbf{1 2 . 3 5}$ & \\
1 & 70.3 & & & \\
2 & 67.8 & 14.35 & 15.35 & Sandy loam \\
3 & 65.3 & 19.35 & 12.85 & Sandy loam \\
4 & 67.8 & 24.35 & 10.35 & Sandy loam \\
5 & 65.3 & 16.85 & 15.35 & Sandy loam \\
Mean & 16.85 & 17.85 & Sandy loam \\
CT & $\mathbf{6 7 . 3}$ & $\mathbf{1 8 . 3 5}$ & $\mathbf{1 4 . 8 5}$ & \\
1 & & & & \\
2 & 62.8 & 24.35 & 12.85 & Sandy loam \\
3 & 65.3 & 24.35 & 10.35 & Sandy loam \\
4 & 62.8 & 24.35 & 12.85 & Sandy loam \\
5 & 65.3 & 19.35 & 15.35 & Sandy loam \\
Mean & 65.3 & 16.85 & 17.85 & Sandy loam \\
LSD & $\mathbf{6 4 . 3}$ & $\mathbf{2 1 . 8 5}$ & $\mathbf{1 3 . 3 5}$ & \\
\hline NS & $\mathbf{2 . 6 6}$ & $\mathbf{2 . 1 5}$ &
\end{tabular}

${ }^{1}$ NS- not significant at $p \leq 0.05$ level of probability

${ }^{2}$ 1....5- replication 
Table 2: Mean bulk density (Bd) and total porosity (TP) of the soil as affected by tillage systems at 0-15 and 15-30 cm soil depths

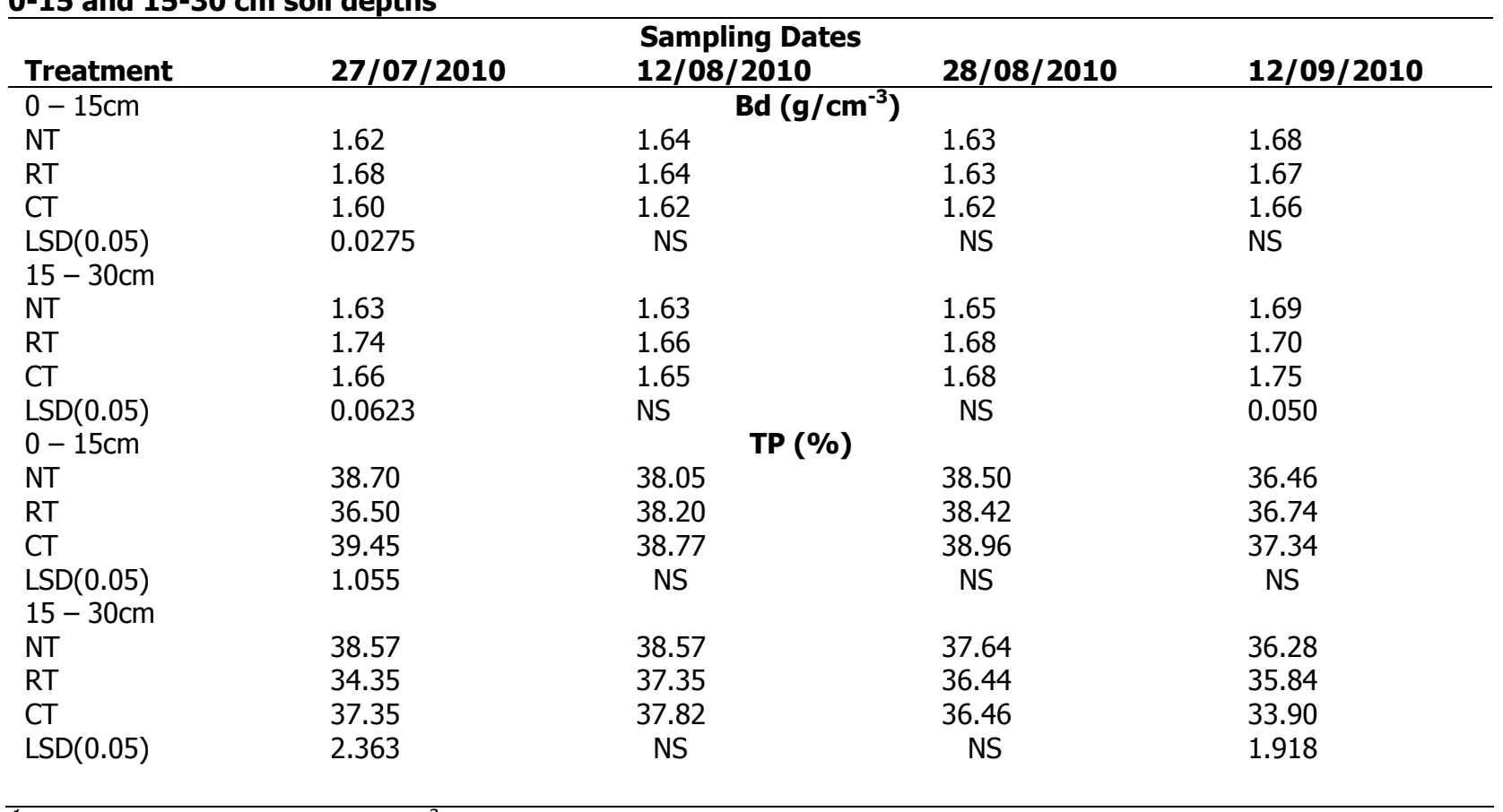

${ }^{1} \mathrm{NS}-$ not significant at $p \leq 0.05,{ }^{2} \mathrm{NT}$

Table 3: Mean volumetric moisture content $(\theta v)$ of the soil as affected by tillage systems at $0-15$ and $15-30 \mathrm{~cm}$ soil depths

\begin{tabular}{|c|c|c|c|c|}
\hline \multirow[b]{2}{*}{ Treatment } & \multicolumn{3}{|c|}{ Sampling Dates } & \multirow[b]{2}{*}{$12 / 09 / 2010$} \\
\hline & $27 / 07 / 2010$ & $12 / 08 / 2010$ & $28 / 08 / 2010$ & \\
\hline $0-15 \mathrm{~cm}$ & \multicolumn{3}{|c|}{$\theta v(\%)$} & \\
\hline NT & 15.24 & 15.60 & 13.03 & 11.74 \\
\hline RT & 14.76 & 14.15 & 14.26 & 11.11 \\
\hline CT & 12.65 & 12.28 & 11.61 & 10.66 \\
\hline $\operatorname{LSD}(0.05)$ & 2.468 & 2.642 & 1.871 & NS \\
\hline \multicolumn{5}{|l|}{$15-30 \mathrm{~cm}$} \\
\hline NT & 16.39 & 15.59 & 12.33 & 11.90 \\
\hline RT & 16.50 & 16.60 & 14.53 & 12.39 \\
\hline CT & 14.91 & 15.39 & 13.10 & 9.02 \\
\hline $\operatorname{LSD}(0.05)$ & NS & 1.104 & 0.860 & 1.123 \\
\hline
\end{tabular}

${ }^{1} \mathrm{NS}$ - not significant at $\mathrm{p} \leq 0.05,{ }^{2} \mathrm{NT}$-no-till, RT-reducetill, CT-conventional tillage.

- no-till, RT-reduce till, CT-conventional tillage

Table 4a: Pearson correlation coefficients $(r)$ between organic carbon, aggregate stability indices and volumetric moisture content $(\Theta v)$ of the soil at $0-15 \mathrm{~cm}$ soil depth

\begin{tabular}{lcccc}
\multicolumn{4}{c}{ Sampling } \\
Parameters & $\mathbf{2 7 / 0 7 / 2 0 1 0}$ & $\mathbf{1 2 / 0 8 / 2 0 1 0}$ & $\mathbf{2 8 / 0 8 / 2 0 1 0}$ & $\mathbf{1 2 / 0 9 / 2 0 1 0}$ \\
\cline { 2 - 4 } & $\mathbf{( \theta v )}$ & $0-15 \mathrm{~cm}$ & $\mathbf{( \theta v )})$ \\
OC & $0.86^{* * *}$ & $\mathbf{( \theta v )}$ & $\mathbf{( \theta v )}$ & $0.87^{* * *}$ \\
MAW & $0.80^{* * *}$ & $0.76^{* *}$ & $0.72^{* *}$ & $0.52^{*}$ \\
MAD & $0.42^{\mathrm{ns}}$ & $0.89^{* * *}$ & $0.68^{* *}$ & $0.19^{\mathrm{ns}}$ \\
ASC & $0.51^{\mathrm{ns}}$ & $0.44^{\mathrm{ns}}$ & $0.72^{* *}$ & $0.59^{*}$ \\
DR & $-0.66^{* *}$ & $0.62^{*}$ & $0.58^{*}$ & $-0.54^{*}$ \\
WSI & $0.58^{*}$ & $-0.71^{* *}$ & $-0.47^{*}$ & $0.65^{* *}$ \\
\hline
\end{tabular}

1-OC-organic carbon, MAW- wet macro aggregate, MAD- dry macro aggregate, ASC- aggregated silt + clay, DRdispersion ratio, WSI- water stability index, $\Theta v$ - volumetric moisture content (\%)

$2-*, * *, * * *$, means significant at $5 \%, 1 \%$ and $0.1 \%$ level of probability

3- degree of freedom (df) of treatments in all analyses made are : tillage (2), blocks (4), error (8) and total (14) 
Table 4b: Pearson correlation coefficients $(r)$ between organic carbon, aggregate stability indices and volumetric moisture content $(\theta \mathrm{v})$ of the soil at $15-30 \mathrm{~cm}$ soil depth

\begin{tabular}{lcccc}
\hline & \multicolumn{4}{c}{ Sampling Dates } \\
\cline { 2 - 5 } Parameters & $\mathbf{2 7 / 0 7 / 2 0 1 0}$ & $\mathbf{1 2 / 0 8 / 2 0 1 0}$ & $\mathbf{2 8 / 0 8 / 2 0 1 0}$ & $\mathbf{1 2 / 0 9 / 2 0 1 0}$ \\
OC & $(\boldsymbol{\theta} \mathbf{v})$ & $15-30 \mathrm{~cm}$ & $\mathbf{( \theta v})$ \\
MAW & $0.22^{\text {ns }}$ & $\mathbf{( \boldsymbol { \theta } v )}$ & $\mathbf{( \theta v})$ & $0.37^{\text {ns }}$ \\
MAD & $0.48^{\text {ns }}$ & $-0.08^{\text {ns }}$ & $0.06^{\text {ns }}$ & $0.51^{*}$ \\
ASC & $0.17^{\text {ns }}$ & $0.19^{\text {ns }}$ & $-0.08^{\text {ns }}$ & $0.47^{\text {ns }}$ \\
DR & $0.58^{*}$ & $0.42^{\text {ns }}$ & $0.18^{\text {ns }}$ & $0.43^{\text {ns }}$ \\
WSI & $-0.50^{*}$ & $-0.04^{\text {ns }}$ & $0.11^{\text {ns }}$ & $-0.55^{*}$ \\
\hline
\end{tabular}

1-OC-organic carbon, MAW- wet macro aggregate, MAD- dry macro aggregate, ASC- aggregated silt + clay, DRdispersion ratio, WSI- water stability index, $\Theta v$ - volumetric moisture content (\%)

$2^{-*}, * *, * * *$, means significant at $5 \%, 1 \%$ and $0.1 \%$ level of probability

3- degree of freedom (df) of treatments in all analyses made are : tillage (2), blocks (4), error (8) and total (14)

\section{CONCLUSION}

The study revealed that, tillage systems significantly $(p \leq 0.05)$ affected physical properties of the soil with greatest influence observed on volumetric moisture content of the soil. The NT and RT treatments, on average, have best of soil physical conditions to

\section{REFERENCES}

Agbede, T.M. (2007). Effects of zero tillage on cassava (Manihot esculenta Crantz) in southwest Nigeria. Nig. J. Soil Sci. 17: $81-86$.

Alegre, J.C., Cassel, D.K., and Amezquita, E. (1991). Tillage systems and soil properties in Latin America. Soil Tillage Res. 20(2-4): 147-163.

Azooz, R.H. and Arshad, M.A. (1996). Soil infiltration and hydraulic conductivity under long term no-tillage and conventional tillage systems. Canadian J. Soil Science 76: 143 - 152.

Barzegar, A.R., Asoodar, M.A., Eftekhar, A.R. and Herbert, S.J. (2004). Tillage effects on soil physical properties and performance of irrigated wheat and Clover in semi arid region. J. Agron. 3(4): $237-242$.

Blake, G.R. and Hartage, K.H. (1986). Bulk density. In: Klute, A. (Ed). Methods of soil Analysis, part $1,2^{\text {nd }}$ edition. Agronomy 9. pp 363-375.

Dao ,H. (1993). Tillage and winter wheat residue management effects on water infiltration and storage. Soil Sci. Soc. Am. J. 57: 1586 1593.

Dec, D., Dorner, J. and Balocchi, O. (2011). Temporal and spatial variability of structure dependent properties of a volcanic ash soil under pasture in southern Chile. Chilean J. Agric. Res. 71(2):293-303.

Ghuman, B.S. and Lal, R. (1984). Water percolation in a tropical Alfisol under conventional ploughing and no-tillage systems of management. Soil Tillage Res. 4: 263-76.

Golchin, A. and Asgari, H. (2008). Land use effect on soil quality indicators in north eastern Iran. Australian J. Soil Res. 46 (1): 27-36. support crop production relative to the CT treatment, and should therefore be employed for sustainable crop production in the area. It is however recommended that, other reduced tillage systems such as animal traction and ridge tillage should be tried to assess their efficacy of improving soil physical quality.

Grema A.K. and Hess, T.M. (1994). The impact of changing rainfall patterns on the efficiency of rainfall utilization in pearl millet - cowpea intercropping systems in north east Nigeria. Aspects of Applied Biology 38:231 238.

Heddadji, D. and Gascuel - Odoux, C. (1999). Topographic and seasonal variations of unsaturated hydraulic conductivity as measured by tension disc infiltrometers at the field scale. Eur. J. Soil Sci. $\quad \mathbf{5 0 : 2 7 5 \quad -}$ 283.

Hillel, D. (1971). Soil and Water: Physical principles and processes. Academy press Inc. California. pp 69-157.

Husnjak, S., Filipovic, D. and Kosutic, S. (2002). Influence of different tillage systems on soil physical properties and crop yield. Rostlinna Vyroba 48(6): 249-254.

Jabro, J.D., Sainju, U.M., Stevens, W.B., Lenssen, A.W., Evans, R.G. (2008). Long-term tillage frequency effects on dryland soil physical and hydraulic properties. Inter. Soil Conserv. Org. Conf. Proc. may 15-23, Budapest, Hungary. pp 1-4.

Kemper,W.D. (1965). Aggregate stability. In: Methods of soil Analysis part 2(ed. C.A.Black). Society of Agronomy, Madison. Pp 511-519.

Kemper,W.D. and Chepil, W.S. (1965). Size distributio $\mathrm{n}$ of Aggregates. In : C.A.Black (Ed.). Methods of soil Analysis, part 2. ASA, Madiso n. Pp 499-510.

Khakural, B.R., Lemme, G.D., Schumacher, T.E. and Lindstrom, M.J. (1992). Effects of tillage systems and landscape on soil. Soil Tillage Res. 25(1):43-52. 
Khan, F., Tahir, A. and Yule, I. J. (2001). Intrinsic implication of different tillage practices on soil penetration resistance and crop growth. Int. J. of Agriculture and Biology. 3(1):23-26.

Logsdon, S.D. and Cambardella, C.A. (2000). Temporal changes in small depthintercontinental soil bulk density. Soil Sci. Soc. Am. J. 64(2): 710-714.

Malquori, A.R. and Cecconi, S. (1962). Determinazione Seriale del Terreno. Agrochimica 6: 198204.

Mapa, R.B., Green, R.E. and Santo, L. (1986). Temporal variability of soil hydraulic properties with wetting and drying subsequent to tillage. Soil Sci. Soc. Am. J.50: 1133-1138.

Marshall, S.E. and Tokunaga, A. (2006). Soil compaction and strength: Measurement methods and influences on perennial grass growth. Ca I- Pac society for range management symposium, grazing for biological conservation. Pp 1-4.

Mbagwu, J.S.C. and Bazzoffi, P. (1989). Properties of soil aggregates as influenced by tillage practices. Soil Use and Management. 15: 180 $-188$.

Middleton, H.E. (1930). Properties of soils which influe nce soil erosion. United States Department of Agriculture Technical Bulletin Number 178.

Mielke, L.N. Wilhelm, W.W., Richards, K.A. and Fenster, C.R. (1984). Soil physical Characteristics of reduce tillage in a wheatfallow system. Transaction of the ASAE. USDA- ARS, Lincoln, Nebraska. Pp 17241728.

Milton da Veiga, Dalvan, J.R. and Jose, M.R. (2009). Aggregate stability as affected by short and long- term tillage systems and nutrient sources of a Hapludox in Southern Brazil. R.Bras.Ci. Solo 33:767-777.

Moran, C.J., Kopi, A.J., Murphy, B.W. and Mc Bratney, A.B. (1988). Comparison of the macropore structure of a sandy loam surface soil horizon subjected to two tillage treatments. Soil Use and Management. 4 (3): 96-101.
SAS (2005). Statistical analysis system (SAS) Version 2005, statistix for windows analytical software, USA.

Sauwa, M.M., Chiroma, A.M., Alhassan, A.B., Yakubu, M. and Noma, S.S. (2012). Chemical quality indicators of an entisol under different tillage practices in Maiduguri, Nigeria. Int. Res. J. Agric. Sci. and Soil Sci. 2(9): 395-399.

Suwardji, P. and Eberbach, P.L. (1998). Seasonal changes of physical properties of an Oxic paleustalf (Red Kandosol) after 16 years of direct drilling or conventional cultivation. Soil Tillage Res. 49: 65-77.

Walkley, A. and Black, I.A. (1934). An examination of the degtjareff method for determining soil organic matter and a proposed modification of the chromic acid titration method. Soil Sci. 37: 29-38. 